OPEN ACCESS

Edited by:

María Serrano,

Miguel Hernández University of Elche,

Spain

Reviewed by:

Mohammad Anwar Hossain,

Bangladesh Agricultural University,

Bangladesh

Basharat Ali,

University of Agriculture, Faisalabad,

Pakistan

*Correspondence:

Hong Wei

weihong@swu.edu.cn

${ }^{t}$ These authors have contributed

equally to this work

Specialty section:

This article was submitted to

Crop and Product Physiology,

a section of the journal

Frontiers in Plant Science

Received: 13 August 2020

Accepted: 28 September 2020

Published: 23 October 2020

Citation:

Zhang S, Chen H, He D, HeX, Yan Y, Wu K and Wei H (2020) Effects of Exogenous Organic Acids on Cd

Tolerance Mechanism of Salix variegata Franch. Under Cd Stress.

Front. Plant Sci. 11:594352.

doi: $10.3389 / \mathrm{fp} / \mathrm{s} .2020 .594352$

\section{Effects of Exogenous Organic Acids on Cd Tolerance Mechanism of Salix variegata Franch. Under Cd Stress}

\author{
Songlin Zhang ${ }^{1,2+}$, Hongchun Chen ${ }^{1,3+}$, Danni He ${ }^{1}$, Xinrui He ${ }^{1}$, Ya Yan ${ }^{3}$, Kejun $W^{1}$ and \\ Hong Wei ${ }^{1 *}$ \\ 'Key Laboratory of Eco-environments in Three Gorges Reservoir Region (Ministry of Education), Chongqing Key Laboratory \\ of Plant Ecology and Resources Research in Three Gorges Reservoir Region, School of Life Sciences, Southwest University, \\ Chongqing, China, ${ }^{2}$ Key Laboratory of Reservoir Aquatic Environment, Chongqing Institute of Green and Intelligent \\ Technology, Chinese Academy of Sciences, Chongqing, China, ${ }^{3}$ Guizhou Provincial Water Conservancy Research Institute, \\ Guiyang, China
}

Chelate induction of organic acids has been recognized to enhance metal uptake and translocation in plants, but the underlying mechanism remains unclear. In this study, seedlings of Salix variegata were hydroponically exposed to the combinations of $\mathrm{Cd}$ $(0$ and $50 \mu \mathrm{M})$ and three exogenous organic acids (100 $\mu \mathrm{M}$ of citric, tartaric, or malic acid). Plant biomass, antioxidant enzymes, non-protein thiol compounds (NPT) content, and the expression of candidate genes associated with $\mathrm{Cd}$ accumulation and tolerance were determined. Results showed that Cd significantly inhibited plant biomass but stimulated the activity of antioxidant enzymes in the roots and leaves, while the lipid peroxidation increased as well. Respective addition of three organic acids greatly enhanced plant resistance to oxidative stress and reduced the lipid peroxidation induced by $\mathrm{Cd}$, with the effect of malic acid showing greatest. The addition of organic acids also significantly increased the content of glutathione in the root, further improving the antioxidant capacity and potential of phytochelatin biosynthesis. Moreover, $\mathrm{Cd}$ induced the expression level of candidate genes in roots of $S$. variegata. The addition of three organic acids not only promoted the expression of candidate genes but also drastically increased Cd accumulation in S. variegata. In summary, application of citric, tartaric, or malic acid alleviated Cd-imposed toxicity through the boost of enzymatic and non-enzymatic antioxidants and candidate gene expression, while their effects on Cd tolerance and accumulation of $S$. variegata differed.

Keywords: cadmium, Salix variegata, organic acid, antioxidant enzymatic system, non-protein sulfhydryl compounds, gene expression

\section{INTRODUCTION}

In recent decades, anthropogenic activities such as industrialization, mining, fossil fuel combustion, and sewage treatment have caused a large increase in the content of metals (e.g., lead, zinc, copper, manganese, and cadmium) in the soil and resulted in serious environmental problems (Wong, 2003). Among all heavy metals, cadmium (Cd) is a highly toxic, biologically undesirable carcinogen, ranking seventh among the top 20 toxic elements (Sanita di Toppi and Gabbrielli, 1999; 
Gill and Tuteja,2011). Cd can be easily absorbed and accumulated by plants because of its high mobility and water solubility (Liu J. et al., 2013; Liu X. et al., 2013). It impairs a series of important physiobiochemical processes and severely inhibits the growth and development of plants (Gill and Tuteja, 2010; Dias et al., 2013). As a non-redox metal, Cd cannot participate in the Fenton-type reaction, but it can cause oxidative stress by the lipid peroxidation and overproduction of reactive oxygen species (ROS) (Wang et al., 2004; Heyno et al., 2008). ROS are extremely harmful to membrane lipids and cellular macromolecules. They oxidize the lipid and membrane and inactivate several enzymes, leading to the eventual cell death (Cuypers et al., 2010). Cd in the environment would also disrupt the balance of ecosystem through accumulation and transmission in the food chain, posing a tremendously negative impact on the ecological environment and human health.

In some Cd-tolerant plant species and hyperaccumulators, a succession of physiochemical mechanisms related to $\mathrm{Cd}$ resistance and detoxification have gradually been formed. For example, the effective ROS defense system, chelation of metals by ligands, cellular compartmentalization, and genetic regulation of metal transporters (Memon and Schroder, 2009; Yuan et al., 2012) can all be employed to alleviate Cd toxicity, as well as other heavy metal ions. In plant cells, enzymatic antioxidants mainly composed of superoxide dismutase (SOD), catalase (CAT), and ascorbate peroxidase (APX) and non-enzymatic antioxidants composed of phenols, carotenoids, and glutathione (GSH) coordinate jointly to scavenge ROS and minimize oxidative stress (Gill and Tuteja, 2010; Mahmud et al., 2018). In addition, studies on rice, wheat, and Arabidopsis have found that thiol compounds such as GSH, phytochelatin (PC), and cysteine (Cys) can sequester free $\mathrm{Cd}$ into plant cell vacuoles to inactivate Cd (Hartley-Whitaker et al., 2001; Gallego et al., 2012). Four main types of proteins, namely, ZRT-IRT-like protein, natural resistance-associated macrophage protein (NRAMP), heavy metal ATPase (P1B-ATPase or CPx-type ATPase), and metal tolerance protein (MTP), play key roles in the sequestration and detoxification of heavy metals (Hanikenne et al., 2008; Pottier et al., 2015). Metallothioneins (MTs) and PCs also synergistically mediate the toxicity of $\mathrm{Cu}$ and $\mathrm{Cd}$ in plants (Guo et al., 2008). For example, Lee et al. (2004) confirmed that the MT AtMT2a and AtMT3 were responsible for Cd resistance in the intact cell of Arabidopsis.

In recent years, "chelate-induced phytoremediation" has attracted widespread attention in the field of phytoremediation (Han et al., 2016). Compared with man-made synthetic chelating agents, natural low-molecular-weight organic acids, a critical group of plant secondary metabolites, such as citric acid, tartaric acid, and malic acid, have higher degradability and lower toxicity and are more in favor of the requirement of environmental friendliness (do Nascimento et al., 2006). Organic acids can increase the solubility and bioavailability of heavy metals in the medium through promoting the desorption of metal ions and forming soluble complexes with metal ions, thus enhancing metal absorption by plants (Wuana et al., 2010; Chen et al., 2020). Moreover, studies have shown that organic acids also play an important role in tricarboxylic acid cycle metabolism, photosynthetic and respiration, nutrient uptake, and toxic metal detoxification in plants (Schulze et al., 2002; Araujo et al., 2012). Under Cd stress, the addition of malic acid can alleviate $\mathrm{Cd}$-induced oxidative damage by regulating the enzymatic and non-enzymatic antioxidants in Miscanthus sacchariflorus (Guo et al., 2017).

Salix variegata Franch. is a perennial shrub of Salicaceae family. It has been proven to have broad application prospects in phytoremediation engineering due to its fast growth rate, strong reproductive capacity, and great $\mathrm{Cd}$ tolerance and enrichment ability in Cd contaminated soil (Jia et al., 2011, 2012; Sun et al., 2012). Previous studies have found that respective application of citric, tartaric, and malic acid significantly increased the proportion of free $\mathrm{Cd}^{2+}$, a favorable form for plants to absorb, in the nutrient solution, and Cd toxicity was substantially mitigated with respect to plant biomass and photosynthesis of $S$. variegata (Chen et al., 2019, 2020). However, the underlying mechanism of how organic acids impact Cd tolerance of $S$. variegata at the physiological and genetic levels is still unclear. Therefore, this study aimed to investigate the effects of individual addition of three organic acids, namely, citric acid, tartaric acid and malic acid, on the physiochemical responses and corresponding gene expression related to Cd accumulation in S. variegata under Cd stress. Our study would provide the scientific basis for promoting the application of chelate-induced phytoremediation technology.

\section{MATERIALS AND METHODS}

\section{Plant Material and Culture Conditions}

The seedlings of $S$. variegata were collected from the bank of Jialing River in Chongqing $\left(29^{\circ} 41^{\prime} 2^{\prime \prime} \mathrm{N}, 106^{\circ} 26^{\prime} 56^{\prime \prime} \mathrm{E}\right)$ on March 30,2018 . Before the experimental treatments, seedlings were transplanted and cultivated with conventional field management, including regular watering and weeding, in the ecological garden of Southwest University. Seedlings with uniform growth parameters were then transplanted into the polyethylene pots $(\phi 18 \mathrm{~cm} \times \mathrm{h} 16 \mathrm{~cm})$ and transferred to a light chamber on May 11, 2018. Each pot was added with $1.7 \mathrm{~L}$ of $1 / 2$ modified Hoagland's nutrient solution ( $\mathrm{pH}$ 5.5) in which the detailed recipe was based on Nawaz et al. (2017). The day and night air temperatures were maintained at 25 and $20^{\circ} \mathrm{C}$, respectively. The day length was $16 \mathrm{~h}$, and the light intensity was $95 \mu \mathrm{mol} \cdot \mathrm{m}^{-2} \cdot \mathrm{s}^{-1}$.

\section{Treatment Test}

After 1 week of preculture, the seedlings were randomly divided into five treatments: (1) $\mathrm{CK}$ group, no $\mathrm{Cd}$ or organic acid addition; (2) Cd group, $50 \mu \mathrm{M}$ of $\mathrm{Cd}$; (3) Cd + citric acid group, $50 \mu \mathrm{M}$ of $\mathrm{Cd}$ and $100 \mu \mathrm{M}$ of citric acid; (4) $\mathrm{Cd}+$ tartaric acid group, $50 \mu \mathrm{M}$ of $\mathrm{Cd}$ and $100 \mu \mathrm{M}$ of tartaric acid; and (5) $\mathrm{Cd}+$ malic acid group, $50 \mu \mathrm{M}$ of $\mathrm{Cd}$ and $100 \mu \mathrm{M}$ of malic acid. The concentrations of $\mathrm{Cd}$ and organic acids were chosen based on the typical content in the natural environment and the results of previous studies (Chen et al., 2020; Guo et al., 2017). All treatments contained three replicates. Cd was added in an aqueous solution as $\mathrm{CdCl}_{2} \cdot 2.5 \mathrm{H}_{2} \mathrm{O}$, and all organic acids 
were added as aqueous solutions of pure acid. The $\mathrm{pH}$ value of nutrient solution in each treatment was 4.09-6.00, and free $\mathrm{Cd}^{2+}$ was detected as the primary form, accounting for 89.696.6\% of the total Cd (Chen et al., 2019, 2020). During the experimentation period, the nutrient solution was continuously aerated and renewed weekly.

\section{Assay of Plant Biomass and Cd Accumulation}

Plants were harvested at 4 weeks after treatment. The roots were first immersed in $20 \mathrm{mM}$ EDTA-Na $\mathrm{Na}_{2}$ solution for $5 \mathrm{~min}$, and then the seedlings were rinsed with distilled water and divided into roots, stems, and leaves. Each part was dried at $80^{\circ} \mathrm{C}$ to constant weight and gravimetrically measured. Dry sample $0.05 \mathrm{~g}$ was digested with concentrated mixed acids $\left(\mathrm{HNO}_{3}: \mathrm{H}_{2} \mathrm{O}_{2}=3: 1\right)$, and the concentration of $\mathrm{Cd}$ was determined by an inductively coupled plasma-optical emission spectrometry (Thermo Fisher, United States).

\section{Assay of Malondialdehyde and Antioxidant Enzymes}

After 4 weeks of treatment, malondialdehyde (MDA) concentration in the roots and leaves of $S$. variegata was measured according to Guo et al. (2004). Briefly, $0.2 \mathrm{~g}$ of fresh tissues was homogenized in $10 \mathrm{~mL}$ of $10 \%$ (vol/vol) trichloroacetic acid (TCA) containing $0.25 \%$ (wt/vol) 2-thiobarbituric acid (TBA). The homogenate was heated at $95^{\circ} \mathrm{C}$ for $30 \mathrm{~min}$ and then quickly cooled on ice. After centrifugation at $10,000 \times g$ for $10 \mathrm{~min}$, the absorbance of the supernatant was measured at 450,532 , and $600 \mathrm{~nm}$. The value for nonspecific absorbance at $600 \mathrm{~nm}$ was subtracted. MDA concentration was expressed as $\mathrm{mmol} \cdot \mathrm{g}^{-1}$ FW by an extinction coefficient of $155 \mathrm{mM}^{-1} \cdot \mathrm{cm}^{-1}$.

Antioxidant enzymes including SOD, peroxidase (POD), CAT, and APX in roots and leaves of $S$. variegata were determined. Fresh sample $0.5 \mathrm{~g}$ was frozen in liquid nitrogen and then homogenized using $5 \mathrm{~mL}$ of $50 \mathrm{mM}$ potassium phosphate buffer ( $\mathrm{pH} 7.0$, containing $0.1 \mathrm{mM}$ EDTA) with prechilled mortar and pestle. The homogenate was centrifuged at $15,000 \times g$ for $20 \mathrm{~min}$ at $4^{\circ} \mathrm{C}$, and the supernatant was used for the assay of enzyme activities. SOD activity was determined according to Beauchamp and Fridovich (1971). The $3 \mathrm{~mL}$ of reaction mixture contained $50 \mathrm{mM}$ potassium phosphate buffer $(\mathrm{pH} 7.0)$, $13 \mathrm{mM}$ methionine, $75 \mu \mathrm{M}$ nitroblue tetrazolium (NBT), $2 \mu \mathrm{M}$ riboflavin, and $0.1 \mathrm{~mL}$ of enzyme extract. One unit of SOD activity was estimated as 50\% reduction of NBT at $560 \mathrm{~nm}$. POD activity was determined using guaiacol as a substrate (Nickel and Cunningham, 1969). The $3 \mathrm{~mL}$ of reaction mixture consisted of $25 \mathrm{mM}$ phosphate buffer ( $\mathrm{pH} 7.0$ ), 0.05\% guaiacol, $1.0 \mathrm{mM}$ $\mathrm{H}_{2} \mathrm{O}_{2}$, and $0.1 \mathrm{~mL}$ of enzyme extract. The increase in guaiacol oxidation was recorded within $3 \mathrm{~min}$ at $470 \mathrm{~nm}$. CAT activity was determined spectrophotometrically by the method of Aebi (1984) with some modifications. The $3 \mathrm{~mL}$ of reaction mixture contained $50 \mathrm{mM}$ potassium phosphate buffer ( $\mathrm{pH}$ 7.0), $10 \mathrm{mM} \mathrm{H}_{2} \mathrm{O}_{2}$, $0.1 \mathrm{mM}$ EDTA, and $0.1 \mathrm{~mL}$ of enzyme extract. The CAT activity was assayed by monitoring the absorbance decrease at $240 \mathrm{~nm}$ as a consequence of $\mathrm{H}_{2} \mathrm{O}_{2}$ disappearance. APX activity was determined according to Nakano and Asada (1981). The $3 \mathrm{~mL}$ of reaction mixture included $25 \mathrm{mM}$ potassium phosphate buffer ( $\mathrm{pH}$ 7.0), $10 \mathrm{mM} \mathrm{H}_{2} \mathrm{O}_{2}, 0.1 \mathrm{mM}$ EDTA, $0.25 \mathrm{mM}$ ascorbate, and $0.1 \mathrm{~mL}$ of enzyme extract. The oxidation activity of ascorbate was observed by the variation in absorbance at $290 \mathrm{~nm}$. The MDA concentration was determined by the TCA-TBA method (Guo et al., 2004).

\section{Analysis of NPTs}

The total NPT was measured according to Duan et al. (2011). One gram of fresh tissue was ground with liquid nitrogen and homogenized with $3 \mathrm{~mL} 5 \%$ (wt/vol) sulfosalicylic acid containing $6.3 \mathrm{mM}$ diethylenetriaminepentaacetic acid. The homogenate was then centrifuged at $12,000 \times g$ for $15 \mathrm{~min}$ at $4^{\circ} \mathrm{C}$, and the supernatant was collected for determination of thiols. For NPT analysis, $0.2 \mathrm{~mL}$ of supernatant was mixed with $2.65 \mathrm{~mL}$ of $0.25 \mathrm{mM}$ Tris- $\mathrm{HCl}$ and $0.15 \mathrm{~mL}$ of $10 \mathrm{mM} 5,5$-dithio2-nitrobenzoic acid (DTNB). The absorbance was measured after $3 \mathrm{~min}$ in a spectrophotometer (UV-2550, SHIMADZU, Japan) at $412 \mathrm{~nm}\left(30^{\circ} \mathrm{C}\right)$. A reagent blank was referred to correct the absorbance of DTNB. NPT concentration was calculated using an extinction coefficient of $13,600 \mathrm{M}^{-1} \cdot \mathrm{cm}^{-1}$. For GSH determination, $1 \mathrm{~g}$ of frozen tissue was homogenized in 5\% TCA ( vol/vol) solution and then centrifuged at $12,000 \times g$ for $15 \mathrm{~min}$ at $4^{\circ} \mathrm{C}$ to obtain the supernatant. Determination of GSH was performed spectrophotometrically by the method of Wang et al. (2016), and the absorbance at $412 \mathrm{~nm}$ was recorded. The concentration of non-GSH NPT was calculated as follows: non-GSH NPT = NPT - GSH (Duan et al., 2011).

\section{Quantitative Real-Time Polymerase Chain Reaction Analysis}

The S. variegata transcriptome database (unpublished data) was mined for genes involved in Cd transportation and detoxification pathways. The gene expression profiles include NRAMP5 of the NRAMP family, metal tolerance protein MTP1 and MTP4, P-type metal ATPase HMA1, HMA3, and HMA5, MT protein MT1A and $M T 2 B$, and GSH $\gamma$-glutamylcysteinyl transferase 1 PCS1.

\section{RNA Extraction}

Total RNA was extracted using mirVana ${ }^{\mathrm{TM}}$ miRNA ISOlation Kit (Ambion, Carlsbad, CA, United States) according to the manufacturer's specifications. The quality and yield of RNA were determined using a NanoDrop 2000 spectrophotometer (Thermo Scientific, United States) and evaluated using agarose gel electrophoresis stained with ethidium bromide.

\section{Real-Time Quantitative Reverse Transcription-Polymerase Chain Reaction}

Quantification was performed with a two-step reaction process: reverse transcription (RT) and polymerase chain reaction (PCR). Briefly, $8 \mu \mathrm{L}$ mixture containing $0.5 \mu \mathrm{g}$ RNA, $2 \mu \mathrm{L}$ of $4 \times g$ DNA wiper mix, and nuclease-free $\mathrm{H}_{2} \mathrm{O}$ was reacted in a GeneAmp ${ }^{\circledR}$ PCR System 9700 (Applied Biosystems, United States) for $2 \mathrm{~min}$ at $42^{\circ} \mathrm{C}$. The mixture was then added with $2 \mu \mathrm{L}$ of $5 \times$ HiScript II Q RT SuperMix II $^{\mathrm{a}}$ and further reacted for $10 \mathrm{~min}$ at $25^{\circ} \mathrm{C}, 30 \mathrm{~min}$ at $50^{\circ} \mathrm{C}$, and $5 \mathrm{~min}$ at $85^{\circ} \mathrm{C}$. The 
$10 \mu \mathrm{L}$ RT reaction mix was diluted 10 times in nuclease-free water and restored at $-20^{\circ} \mathrm{C}$. Real-time PCR was performed using LightCycler ${ }^{\circledR}$ 480II Real-time PCR Instrument (Roche, Swiss) with a $10 \mu \mathrm{L}$ PCR reaction mixture consisting of $1 \mu \mathrm{L}$ of cDNA, $5 \mu \mathrm{L}$ of $2 \times$ QuantiFast $^{\circledR}$ SYBR $^{\circledR}$ Green PCR Master Mix (Qiagen, Germany), $0.2 \mu \mathrm{L}$ of forward primer, $0.2 \mu \mathrm{L}$ of reverse primer, and $3.6 \mu \mathrm{L}$ of nuclease-free water. Reactions were incubated in a 384-well optical plate (Roche, Swiss) at $95^{\circ} \mathrm{C}$ for $10 \mathrm{~min}$, followed by 40 cycles of $95^{\circ} \mathrm{C}$ for $10 \mathrm{~s}$ and $60^{\circ} \mathrm{C}$ for $30 \mathrm{~s}$. Each sample was run in triplicate for analysis, and three replicates in each treatment were determined. At the end of the PCR cycles, melting curve analysis was performed to validate the specific generation of the expected PCR product. The primer sequences were designed in the laboratory and synthesized by Generay Biotech (Generay, PRC) based on the mRNA sequences obtained from the NCBI database (Table 1).

\section{Statistical Analyses}

One-way analysis of variance and Tukey test were performed for plant biochemical data using SPSS 22.0 software, and 5\% probability level was applied to distinguish significant difference among treatments. All results were expressed as the mean $\pm \mathrm{SE}$ from three replicates.

\section{RESULTS}

\section{Plant Biomass and Cd Accumulation}

As shown in Table 2, the tissue biomass of $S$. variegata was significantly inhibited by $\mathrm{Cd}$ except the leaf, compared with CK. Individual addition of the three exogenous organic acids markedly increased plant biomass as well as root and stem biomass under Cd stress. Among them, the root, stem, and total plant biomass in the $\mathrm{Cd}+$ malic acid treatment were 201,241, and $208 \%$ of that in the Cd treatment group, respectively, exhibiting the greatest effect on the mitigation of Cd-induced biomass of S. variegata (Table 2).

TABLE 1 | Gene primers for RT-qPCR.

\begin{tabular}{lll}
\hline Gene name & Forward primer & Reverse primer \\
\hline NRAMP5 & TCATTTAGCTTCCATTCGC & GGTCCCATCTTGGTGTTACT \\
MTP1 & CAAGTCTCCAGCAAATACG & CACGCCAACAGACTGAATA \\
MTP4 & GTAGAAGCTCGGGAAACAG & GCAACCAATCCTACCACAT \\
HMA1 & TTGTGCAGGATGATATTAACCG & TTGGATAGGTGGCTGTGT \\
HMA3 & TCCTCAGAAAGCAGTCATAGC & ATCGACAACAACTCCATCAAT \\
HMA5 & ACGTGTTGATCGCTTAGGAA & ATCCGTGGACTCAAATATTGG \\
MT1A & AGGTGTTGCACCAGTTAAG & CCATTCTCAGCACCGAAG \\
MT2B & CCTGAGTTCTCCGAGACC & CATCCTAACCGGAGCGACA \\
PCs1 & GAAGTGATATGGTCAATGGTCG CAATGTGGTATGTTCCGGT \\
GAPDH-Salix & TAGGCTGTTGGAAGGTTC & TGCCTTCTTCTCAAGCCT \\
matsudana & TGCCA & GACAGT
\end{tabular}

The expression levels of mRNA were normalized to Salix matsudana-GAPDH and were calculated using the $2^{-\Delta \Delta C t}$ method (Livak and Schmittgen, 2001).
TABLE 2 | Effect of organic acids on the biomass of S. variegata under Cd stress.

\begin{tabular}{lcccc}
\hline Treatments & \multicolumn{4}{c}{ Plant biomass (g) } \\
\cline { 2 - 5 } & Root & Stem & Leaf & Total \\
\hline CK & $1.30 \pm 0.06^{\mathrm{b}}$ & $1.15 \pm 0.03^{\mathrm{ab}}$ & $0.68 \pm 0.06^{\mathrm{a}}$ & $3.12 \pm 0.1^{\mathrm{b}}$ \\
$\mathrm{Cd}$ & $0.83 \pm 0.02^{\mathrm{a}}$ & $0.75 \pm 0.07^{\mathrm{a}}$ & $0.53 \pm 0.02^{\mathrm{a}}$ & $2.12 \pm 0.15^{\mathrm{a}}$ \\
$\mathrm{Cd}+$ citric acid & $1.34 \pm 0.11^{\mathrm{b}}$ & $1.17 \pm 0.07^{\mathrm{ab}}$ & $0.71 \pm 0.05^{\mathrm{a}}$ & $3.22 \pm 0.25^{\mathrm{b}}$ \\
$\mathrm{Cd}+$ tartaric acid & $1.29 \pm 0.15^{\mathrm{b}}$ & $1.47 \pm 0.05^{\mathrm{bc}}$ & $0.95 \pm 0.04^{\mathrm{a}}$ & $3.71 \pm 0.26^{\mathrm{bc}}$ \\
Cd + malic acid & $1.67 \pm 0.10^{\mathrm{b}}$ & $1.82 \pm 0.04^{\mathrm{c}}$ & $0.92 \pm 0.07^{\mathrm{a}}$ & $4.41 \pm 0.17^{\mathrm{c}}$
\end{tabular}

Values are mean $\pm S E(n=3)$. Values with different letters indicate significant differences between treatments at $P<0.05$.

Cd concentration in tissues of $S$. variegata varied with the types of organic acids added (Table 3). As compared with the Cd group, treatment with citric acid significantly increased the root $\mathrm{Cd}$ by $37 \%$, whereas the stem $\mathrm{Cd}$ was notably reduced to $75 \%$ of that in the Cd-treated group by malic acid. In the leaves, the addition of tartaric acid greatly increased Cd concentration by $81 \%$ relative to the $\mathrm{Cd}$ treatment group. Moreover, respective addition of organic acids significantly increased Cd accumulation in tissues of $S$. variegata, regardless of the types. The total plant Cd amounts in citric, tartaric, and malic acid treatments were 209,190 , and $178 \%$ of that in $\mathrm{Cd}$ treatment group, respectively (Table 3 ).

\section{Lipid Peroxidation and Antioxidant Enzymes}

The MDA content of membrane lipid peroxidation in roots and leaves is shown in Figure 1. Under Cd stress, the MDA content increased by 103 and $69 \%$ in roots and leaves, respectively, as compared with CK. Respective addition of three organic acids alleviated lipid peroxidation in plant roots and leaves at different degrees. Specifically, the MDA content in roots of S. variegata was significantly decreased in the treatment group of citric, tartaric, and malic acid by 30,51 and $68 \%$, respectively, relative to $\mathrm{Cd}$ treatment group. While the MDA content in leaves only decreased to $71 \%$ in the treatment of malic acid as compared with Cd treatment group (Figure 1).

To confirm whether the effect of organic acids on MDA content in the roots and leaves of S. variegata under Cd stress was due to the activation of antioxidant systems, we measured the activities of key antioxidant enzymes (SOD, POD, CAT, and APX; Figures 2, 3). In roots, the activities of SOD and CAT significantly increased by 30 and 133\%, respectively, under $\mathrm{Cd}$ stress. Individual addition of citric acid and malic acid greatly increased the POD activity to $201 \%$ and to $324 \%$ of that in Cd treatment group, respectively. Tartaric acid treatment significantly increased the POD activity by $42 \%$, whereas the APX activity was substantially reduced by $39 \%$. Compared with Cd-treated group, treatment with organic acids did not change the activities of SOD and CAT (Figure 2).

In the leaves, Cd induced the activities of SOD, POD, and APX by 82,36 , and $210 \%$, respectively, as compared with CK (Figure 3). Citric acid addition reduced the activities of SOD, POD, and APX by 31, 34, and 55\%, respectively. Treatment of 
three organic acids had negligible effect on SOD activity, while they greatly influenced the activities of POD and APX. The addition of tartaric acid significantly reduced the APX activity by $39 \%$, whereas malic acid treatment increased the POD activity by $45 \%$, as compared with the Cd-treated group (Figure 3 ). CAT activity remained relatively stable except the treatment of tartaric acid showing considerably higher activity of CAT than the CK group.

\section{Contents of Non-protein Sulfhydryl Compounds}

As shown in Figure 4, under Cd stress, the content of total NPT in roots and leaves of $S$. variegata significantly increased by 29 and $10 \%$, respectively, as compared with CK. The nonGSH NPT content in roots and leaves also increased by 71 and $25 \%$, respectively. However, GSH content was not affected by $\mathrm{Cd}$. The addition of citric acid or malic acid markedly increased the content and composition of NPT in roots of $S$. variegata (Figure 4). The contents of NPT, GSH, and non-GSH NPT of roots in citric acid treatment group were 167, 185, and 156\% of that in Cd treatment group, respectively, whereas their contents in the malic acid treatment group were 161, 180, and $149 \%$ of that in Cd treatment group, respectively. In contrast, tartaric acid treatment showed the opposite tendency (Figure 4). The contents of total NPT and non-GSH NPT in roots significantly decreased as tartaric acid was added, whereas GSH content showed a notable increase compared with the Cd-treated group. Precisely, the contents of NPT, GSH, and non-GSH NPT of roots in the tartaric acid treatment were 83,131 , and $53 \%$ of the Cd treatment group, respectively.

In contrast, treatment with each organic acid had little impact on NPT and GSH in leaves of S. variegata, except that non-GSH NPT was reduced to $82 \%$ of that in the Cd-treated group by citric acid. In general, the contents of NPT and non-GSH NPT in roots of $S$. variegata were higher than that in leaves under each treatment (Figure 4).

\section{Expression of $\mathrm{Cd}$ Accumulation and Tolerance Candidate Genes}

In order to investigate the effects of organic acids on the expression levels of nine candidate genes involved in metal transport and detoxification in roots and leaves of S. variegata, qRT-PCR analysis was performed on these nine genes (Figures 5, 6). In roots, $\mathrm{Cd}$ significantly induced the

TABLE 3 | Effect of organic acids on Cd concentration and accumulation of S. variegata under Cd stress.

\begin{tabular}{|c|c|c|c|c|c|c|c|}
\hline \multirow[t]{2}{*}{ Treatments } & \multicolumn{3}{|c|}{ Cd concentration $\left(\mathbf{m g} \cdot \mathbf{k g}^{-1}\right)$} & \multicolumn{4}{|c|}{ Cd accumulation $\left(\mu \mathrm{g} \cdot\right.$ plant $\left.^{-1}\right)$} \\
\hline & Root & Stem & Leaf & Root & Stem & Leaf & Total \\
\hline $\mathrm{Cd}$ & $232.43 \pm 13.10^{a b}$ & $33.77 \pm 1.53^{\mathrm{bc}}$ & $4.03 \pm 0.18^{a b}$ & $191.85 \pm 6.38^{a}$ & $25.76 \pm 4.85^{a}$ & $2.15 \pm 0.04^{\mathrm{a}}$ & $219.76 \pm 4.21^{a}$ \\
\hline $\mathrm{Cd}+$ citric acid & $320.23 \pm 12.44^{c}$ & $27.77 \pm 1.02^{a b}$ & $3.10 \pm 0.17^{\mathrm{a}}$ & $425.85 \pm 24.69^{b}$ & $32.43 \pm 5.85^{a b}$ & $2.19 \pm 0.33^{a}$ & $460.47 \pm 18.53^{b}$ \\
\hline $\mathrm{Cd}+$ tartaric acid & $274.97 \pm 7.78 b^{c}$ & $39.80 \pm 1.86^{c}$ & $7.33 \pm 0.32^{\mathrm{c}}$ & $351.06 \pm 31.52^{b}$ & $58.70 \pm 4.25^{\mathrm{c}}$ & $6.84 \pm 1.33^{b}$ & $416.60 \pm 34.05^{b}$ \\
\hline $\mathrm{Cd}+$ malic acid & $204.87 \pm 8.37^{a}$ & $25.23 \pm 0.52^{\mathrm{a}}$ & $5.47 \pm 0.37^{b}$ & $340.85 \pm 18.43^{b}$ & $45.78 \pm 0.36^{b c}$ & $5.02 \pm 0.63^{a b}$ & $391.65 \pm 19.32^{b}$ \\
\hline
\end{tabular}

Values are mean $\pm S E(n=3)$. Values with different letters indicate significant differences between treatments at $P<0.05$.
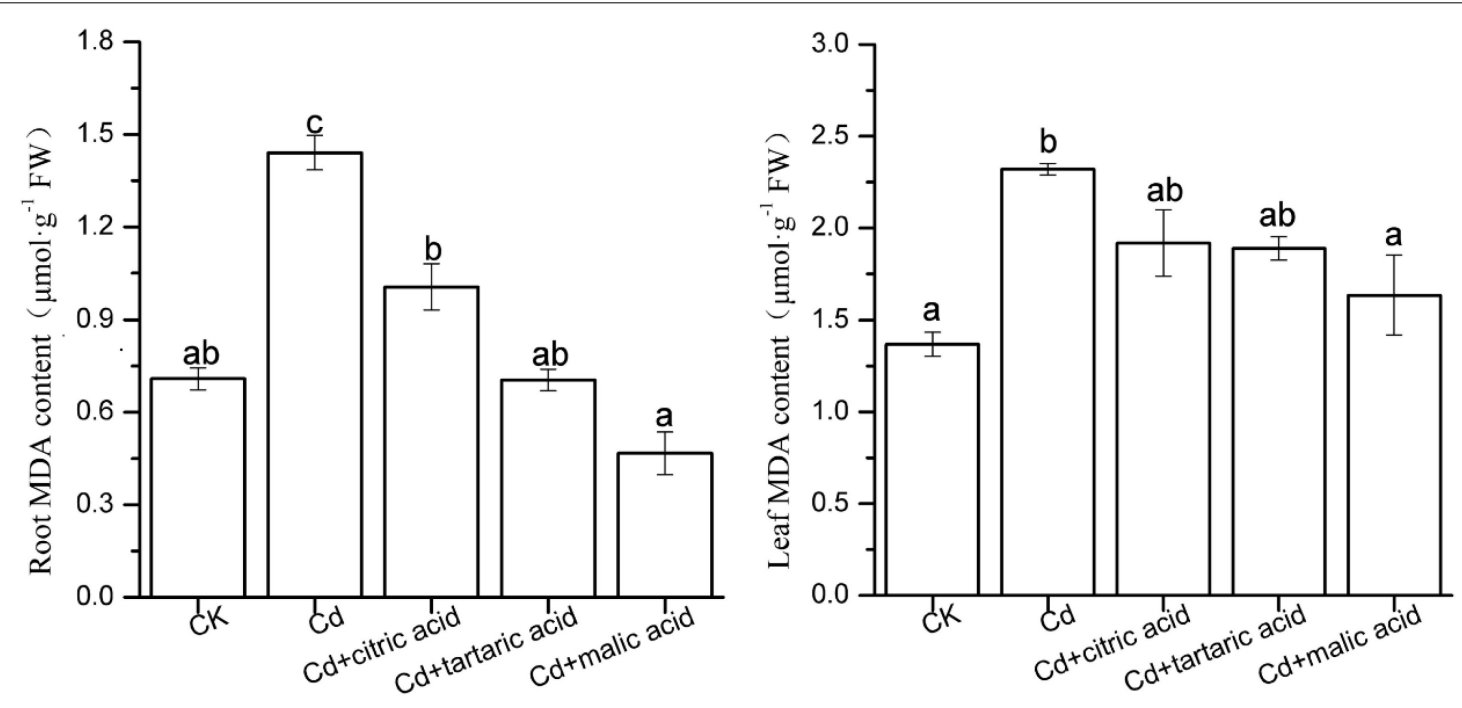

FIGURE 1 | Effects of $100 \mu \mathrm{M}$ of exogenous organic acid (citric, tartaric, or malic acid) on lipid peroxidation of the roots and leaves of $S$. variegata exposed to $50 \mu \mathrm{M}$ of $\mathrm{Cd}$ for 4 weeks. Values are means $\pm \mathrm{SE}(n=3)$. Different letters indicate significant difference between treatments at $P<0.05$. 
expression level of P-type metal ATPase protein HMA1 and PC synthase family protein PCS1, reaching $195 \%$ and 30.45 times of CK, respectively (Figure 5). MT MT1A, MT2B, and P-type metal ATPase protein HMA3 were disrupted by $\mathrm{Cd}$, and their expression levels were significantly down-regulated, reaching only 53, 77, and $42 \%$ of CK, respectively (Figure 5). The expression level of other candidate genes in $\mathrm{Cd}$ treatment group was similar with that in CK. Respective treatment by citric, tartaric, and malic acid had varying effects on the expression levels of nine candidate genes in the root tissues of S. variegata. HMA1 expression was further up-regulated by the addition of tartaric acid or malic acid, reaching 157 and $173 \%$ times of that in the Cd treatment group, respectively. PCS1 was down-regulated under the treatment of malic acid, but still significantly higher than CK. The expression of HMA3 in roots was greatly upregulated after the respective treatment with citric acid, tartaric acid, and malic acid, reaching up to 223,261 , and $175 \%$ of that in the $\mathrm{Cd}$ treatment group, respectively. No significant variation in the expression of MT1A and MT2B was observed between organic acid treatments and $\mathrm{Cd}$ treatment group. The expression levels of NRAMP5 and MTP4 increased significantly in the citric acid and tartaric acid treatment groups, whereas HMA5 was significantly up-regulated only in the citric acid-treated group, and AtMTP1 did not vary between treatments.

In the leaves, $\mathrm{Cd}$ stress significantly increased the expression level of MTP4 and HMA5 by 64 and $148 \%$, respectively, as compared with CK (Figure 6). Among the nine candidate genes, only MT1A was markedly down-regulated by Cd, holding $72 \%$ of CK. The expression level of the other candidate genes in $\mathrm{Cd}$ treatment group was similar to that in CK. Respective addition of citric, tartaric, and malic acid greatly influenced the expression of nine candidate genes. In the citric acid treatment group, the expression levels of NRAMP5, MTP1, MTP4, HMA1, HMA3, MT1A, MT2B, and PCS1 were 6.96, 2.82, 1.70, 2.28, 1.97, 1.82,
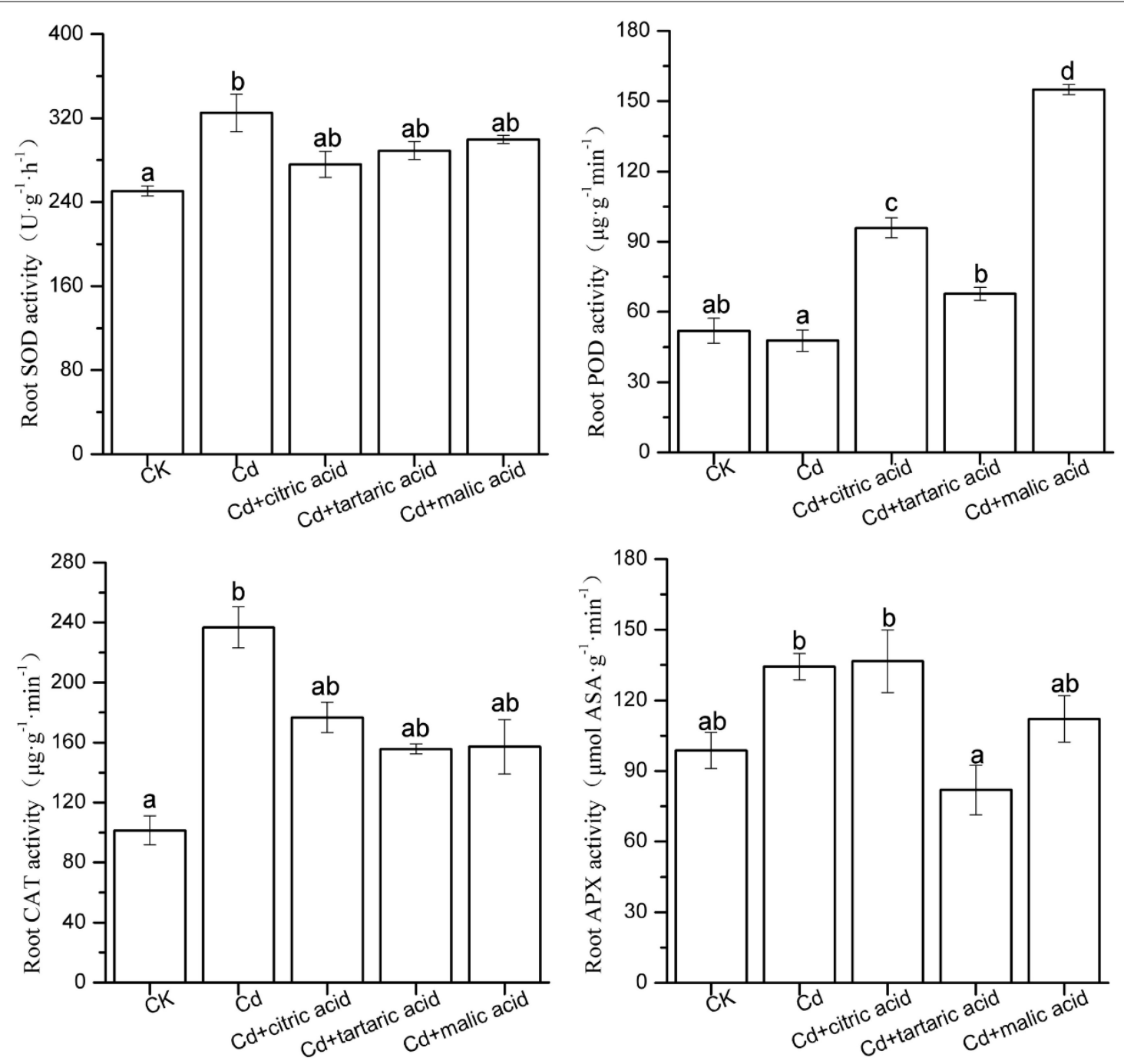

FIGURE 2 | Effects of $100 \mu \mathrm{M}$ of exogenous organic acid (citric, tartaric, or malic acid) on the antioxidant enzymes in roots of $S$. variegata exposed to $50 \mu \mathrm{M}$ of Cd for 4 weeks. Values are means \pm SE $(n=3)$. Different letters indicate significant difference between treatments at $P<0.05$. 

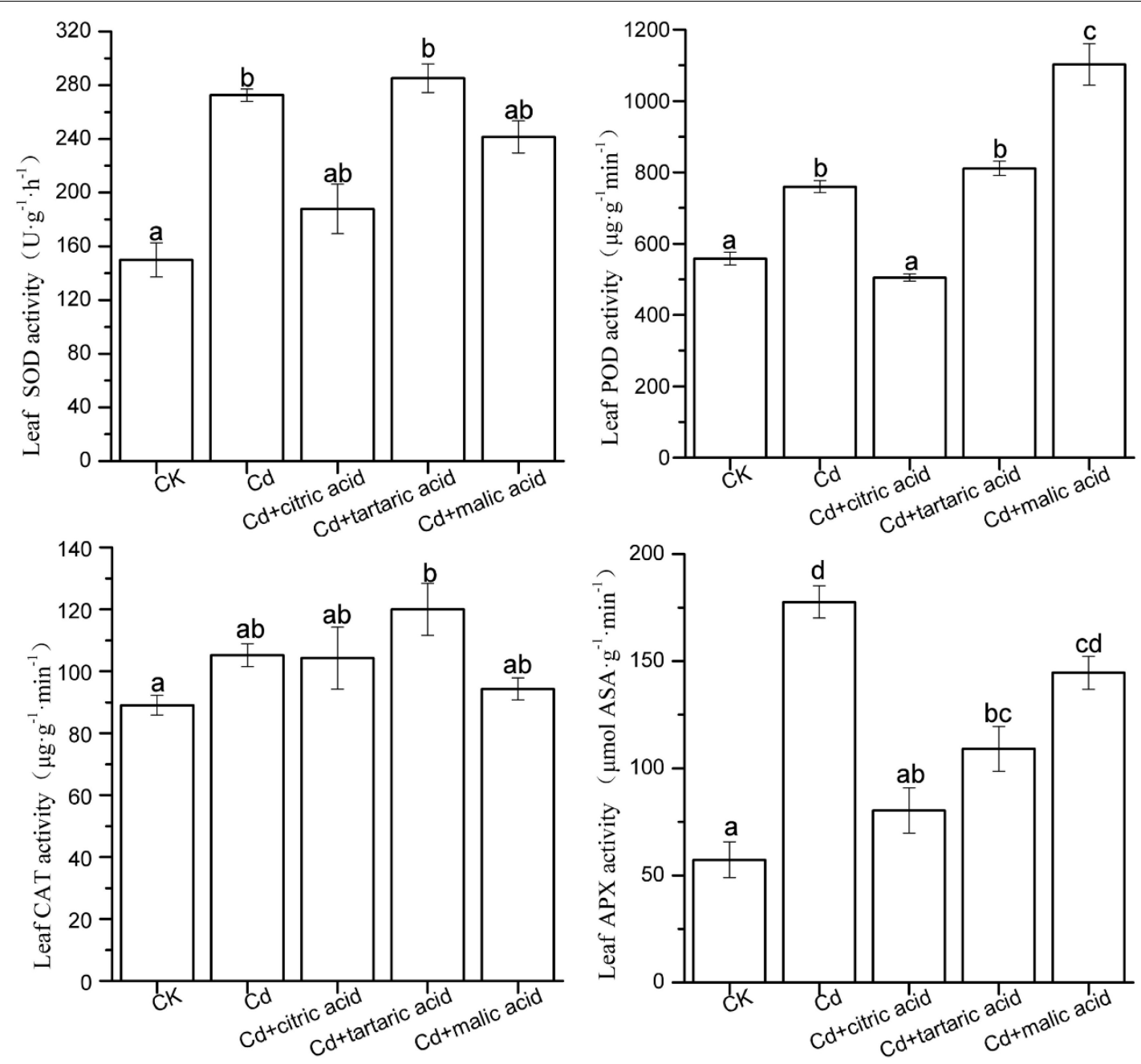

FIGURE 3 | Effects of $100 \mu \mathrm{M}$ of exogenous organic acid (citric, tartaric, or malic acid) on the antioxidant enzymes in leaves of $S$. variegata exposed to $50 \mu \mathrm{M}$ of Cd for 4 weeks. Values are means \pm SE $(n=3)$. Different letters indicate significant difference between treatments at $P<0.05$.

2.42, and 2.90 times of that in Cd treatment group, respectively. In contrast, the addition of tartaric acid decreased the expression levels of MTP1, MTP4, HMA3, HMA5, MT2B, and PCS1 to 60, 47, $80,15,39$, and $28 \%$ of that in Cd treatment group, respectively. The expression levels of NRAMP5 and PCS1 were substantially higher in malic acid treatment, reaching 7.51 and 1.62 times of that in Cd treatment group, respectively, whereas the expression levels of MTP1, HMA3, HMA5, MT1A, and MT2B decreased to $52,72,37,78$, and $50 \%$ of that in the $\mathrm{Cd}$ treatment group, respectively (Figure 6).

\section{DISCUSSION}

$\mathrm{Cd}$ is a highly toxic element with no known biological function in plants and can interfere with cellular enzyme system, oxidative stress reaction, and nutrient metabolism within plants (Irfan et al., 2013). Plant resistance to Cd is mainly determined by physiochemical tolerance, metal transport and sequestration, and antioxidant reactions (Jin et al., 2008). Examining the plant physiochemical response to different organic acids addition under Cd stress would improve our understanding of the mechanistic role of organic acids in $\mathrm{Cd}$ alleviation and detoxification in plants. The present study showed that the biomass of $S$. variegata exposed to Cd was markedly increased by organic acids, among which the malic acid exerted the most obvious influence. On the other hand, although Cd content in the tissues of $S$. variegata varied with the types of organic acids, the total $\mathrm{Cd}$ accumulation in the groups treated with organic acids was still rather higher than that in Cd-treated group. This indicates that application of exogenous organic acids is a promising approach for the phytoremediation of heavy metal contaminated soil. The presence of organic acid in the nutrient solution may alter the speciation of elements and thus plant uptake to Cd and other essential ions can be drastically modified (Najeeb et al., 2011). Therefore, the effect of different organic acids to the absorption of macronutrients, with or without $\mathrm{Cd}$, should be fully examined in the future research. The Cd-induced 

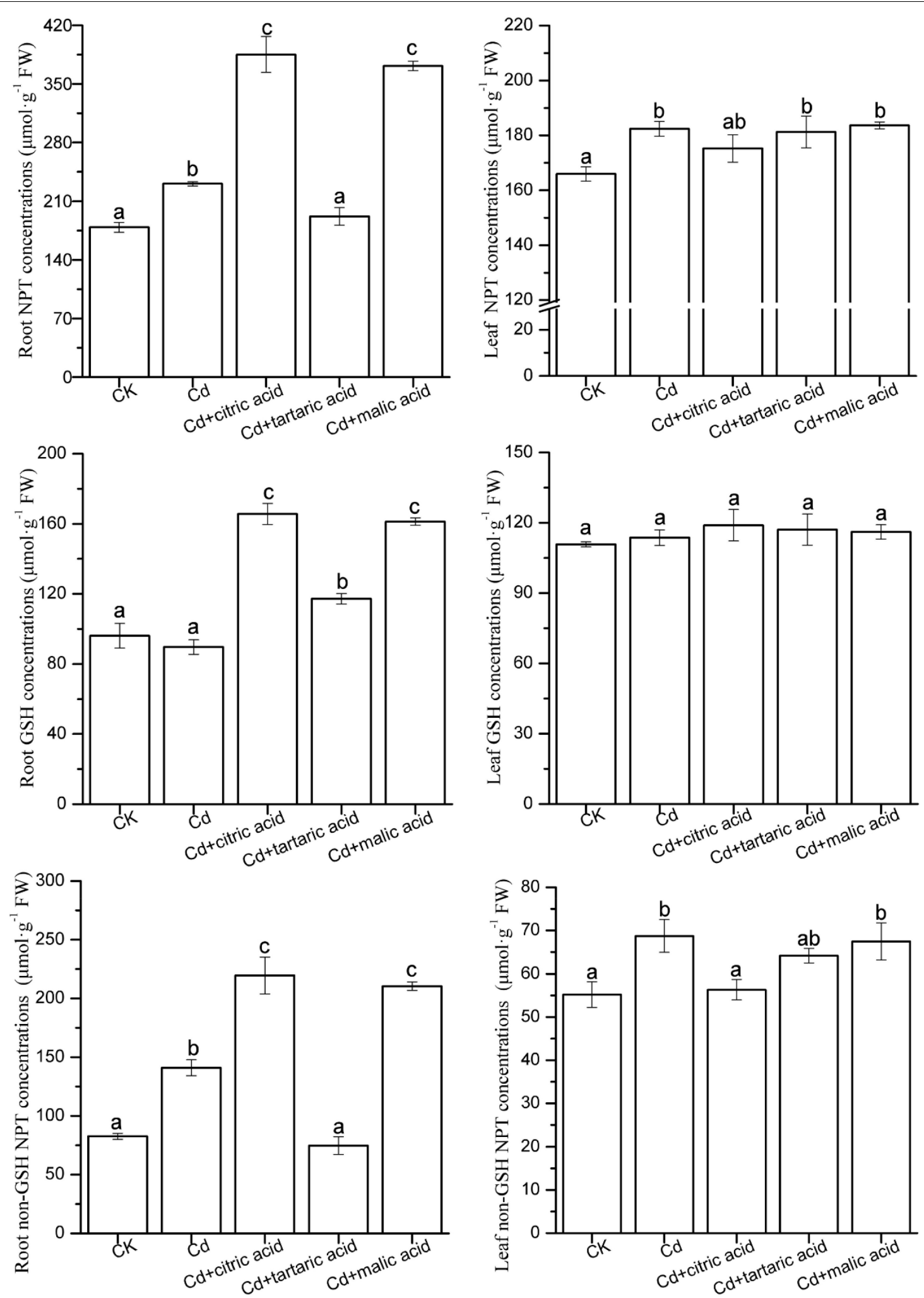

FIGURE 4 | Effects of $100 \mu \mathrm{M}$ of exogenous organic acid (citric, tartaric, or malic acid) on the concentrations of NPT, GSH, and non-GSH NPT in roots and leaves of S. variegata exposed to $50 \mu \mathrm{M}$ of Cd for 4 weeks. Values are means $\pm \mathrm{SE}(n=3)$. Different letters indicate significant difference between treatments at $P<0.05$. 

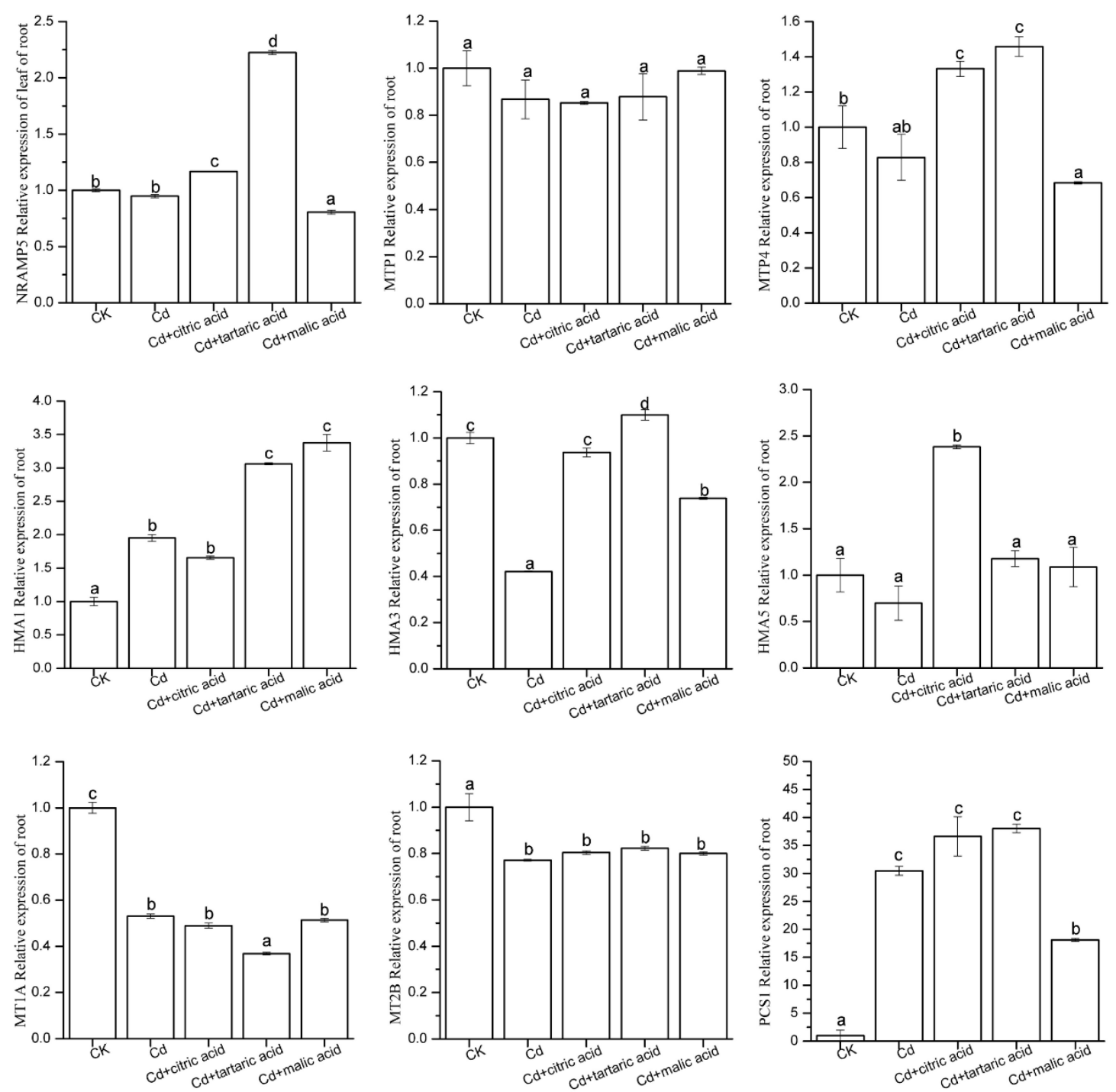

FIGURE 5 | Effect of $100 \mu \mathrm{M}$ of exogenous organic acid (citric, tartaric, or malic acid) on the expression level of candidate genes related to Cd transportation and detoxification in the roots of $S$. variegata exposed to $50 \mu \mathrm{M}$ of Cd for 4 weeks. Values are means \pm SE $(n=3)$. Different letters indicate significant difference between treatments at $P<0.05$.

ROS production is one of the main consequences poisonous to plants. Cd is a non-redox active transition metal that indirectly causes excessive production of ROS by inhibiting the antioxidant defense system or by stimulating membrane-bound NADPH oxidase (Pandey and Singh, 2012; Chmielowska-Bak et al., 2014). Excessive ROS can cause membrane lipid peroxidation, in which the oxygenolysis of lipids containing carbon-carbon double bonds occurs and MDA is produced as the final product. Therefore, increasing MDA content is generally considered to be a hallmark of oxidative damage in plants under metal stress (Najeeb et al., 2011). In this study, Cd treatment resulted in a significant increase in MDA content in roots and leaves of S. variegata. Similar results have been reported in Pisum sativum (Pandey and Singh, 2012) and Brassica juncea (Kaur et al., 2017). Yang et al. (2007) also found that MDA increased in leaf cells of rapeseed plants (Brassica napus) under $\mathrm{Cd}$ exposure. The content of MDA in the leaves of $S$. variegata was higher than that in the roots, indicating that leaf membrane lipid peroxidation suffered more severely than that of roots under $50 \mu \mathrm{M} \mathrm{Cd}$. This is consistent with the findings of Li who studied ramie (Boehmeria nivea) under Cd stress (Li, 2014). Photosynthesis is the main source of ROS produced in plants. Cd causes degradation of Chl and Car and inhibits their biosynthesis, thereby interfering with the electron transport rate of PSI and PSII and leading to ROS accumulation (Touiserkani and Haddad, 2012). The respective addition of citric acid, tartaric acid, and malic acid alleviated lipid peroxidation in the roots and leaves of $S$. variegata, and the malic acid had the most significant effect.

Antioxidant enzymes play important roles in plant adaptation to abiotic stresses. Enhancement of ROS scavenging, a strategy 

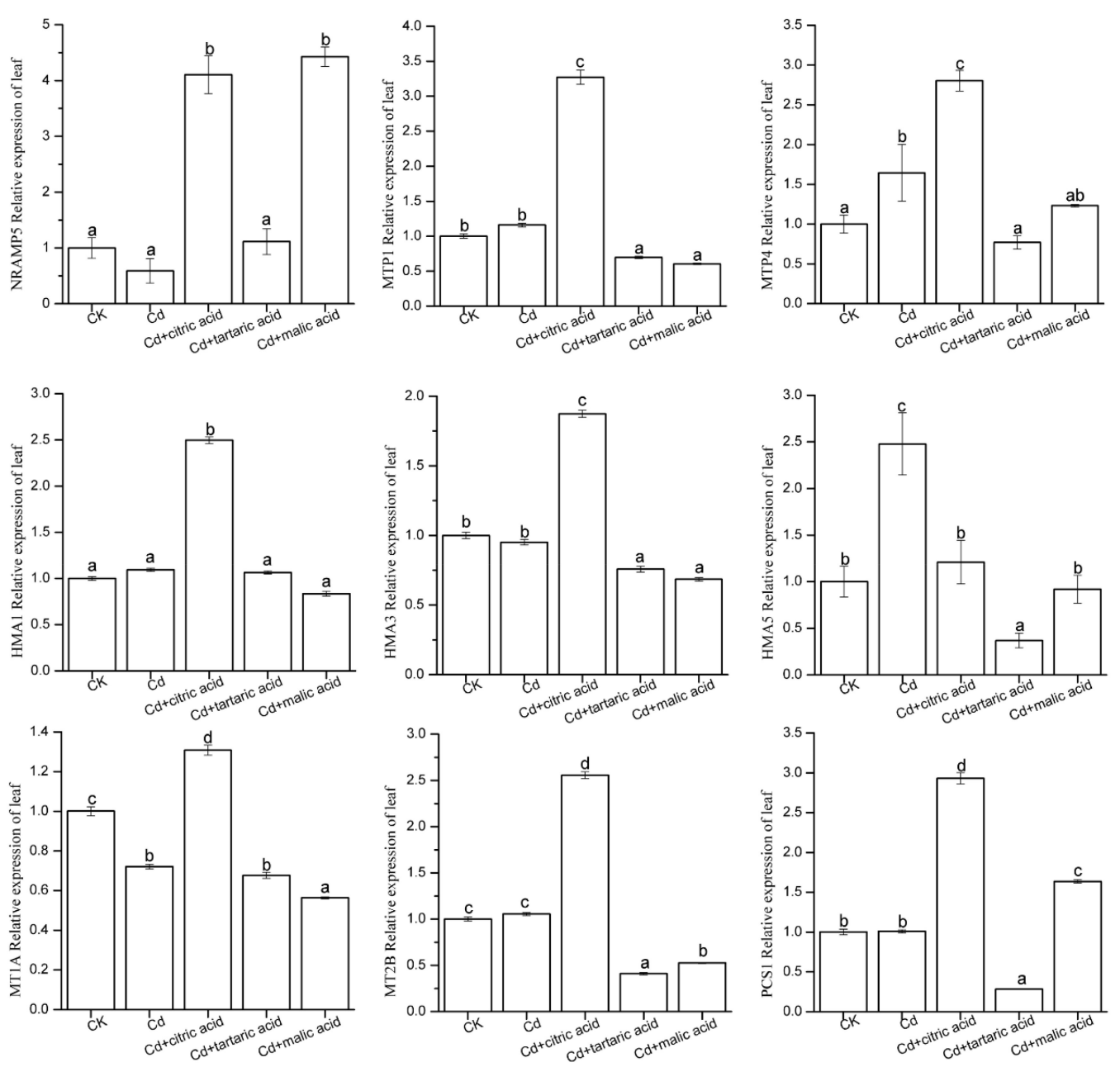

FIGURE 6 | Effect of $100 \mu \mathrm{M}$ of exogenous organic acid (citric, tartaric, or malic acid) on the expression level of candidate genes related to Cd transportation and detoxification in the leaves of $S$. variegata exposed to $50 \mu \mathrm{M}$ of Cd for 4 weeks. Values are means \pm SE $(n=3)$. Different letters indicate significant difference between treatments at $P<0.05$.

to cope with $\mathrm{Cd}$ stress, can be achieved by the regulation of various antioxidant enzyme activities in plants (Smeets et al., 2008). In this study, Cd stress significantly stimulated the activity of SOD and CAT in roots and SOD, POD, and APX in leaves of $S$. variegata. SOD is an important antioxidant enzyme that provides the first line of defense against superoxide anions by catalyzing the conversion of $\mathrm{O}_{2}^{-}$to $\mathrm{H}_{2} \mathrm{O}_{2}$, and $\mathrm{O}_{2}$. CAT has high conversion rate and can catalyze the decomposition of $\mathrm{H}_{2} \mathrm{O}_{2}$ into $\mathrm{H}_{2} \mathrm{O}$ and $\mathrm{O}_{2}$. Similarly, POD, and APX are also important antioxidant enzymes, both of which promote the decomposition of $\mathrm{H}_{2} \mathrm{O}_{2}$ (El-Beltagi and Mohamed, 2013). The POD activity in the roots of $S$. variegata increased significantly under the respective addition of three organic acids, and leaf POD activity also greatly increased after the malic acid addition. The increase of these enzymatic activities may be attributed to the enhanced expression of relevant antioxidative enzyme genes such as POD1, $\mathrm{Cu} / \mathrm{Zn}-\mathrm{SOD}$, and GPX1 induced by organic acids (Guo et al., 2017). This also indicates that organic acid supply enhances the resistance of $S$. variegata to Cd-caused oxidative stress. However, the tartaric acid treatment significantly reduced APX activity in tissues of $S$. variegata. This may be related to the chelation of $\mathrm{Cd}$ by organic acids, which alleviates $\mathrm{Cd}$-induced oxidative stress and ROS, and $\mathrm{H}_{2} \mathrm{O}_{2}$ accumulation would thus greatly decrease (Ali et al., 2015).

The chelation of Cd by sulfhydryl substances (GSH, PC, Cys, etc.) is also one of the dominant detoxification mechanisms in plants. The sulfhydryl group has a strong affinity with $\mathrm{Cd}$, and the formed nontoxic complex can exist in the cytoplasm or be transported to the vacuole, which reduces the toxicity and migration of Cd ions within tissues (Li et al., 2011). The present study showed that increased NPT content in the roots and leaves of $S$. variegata under Cd stress was mainly the increase of nonGSH NPT content, which is consistent with the results of Sun et al. (2005). In this study, the individual addition of citric acid and malic acid significantly increased the non-GSH NPT content in the roots of $S$. variegata under Cd stress but that content in tartaric acid treatment group decreased significantly, which may be associated with the differential effect of organic acids on Cd 
absorption capacity and chelation ability in this species. GSH, a precursor for PC biosynthesis, participates in reactive oxygen metabolism as a crucial non-enzymatic antioxidant. A rational GSH and PC balance in plants has an important effect on plant tolerance to $\mathrm{Cd}$, and elevated GSH increases the capacity of plants against Cd-imposed oxidant damages (Semane et al., 2007; Hasanuzzaman et al., 2012). In this study, respective addition of three organic acids markedly increased the GSH content in roots of $S$. variegata under Cd stress, indicating that this species could sufficiently produce and supplement the GSH for PC biosynthesis and antioxidant consumption in the existence of organic acids.

In the regard of plant adaptation to heavy metals, woody species and herbaceous species may have similar physiological and molecular mechanisms, which establish the foundation for the absorption, transport, storage, and detoxification of heavy metals (Luo et al., 2016). However, studies of heavy metal transport in plants have shown that woody plants may have more complex mechanisms than herbaceous (Migeon et al., 2010; Yamaguchi et al., 2011). NRAMPs maintain the equilibrium state of metals by translocating divalent and trivalent ions in plants. In this study, Cd had little impact on the expression of NRAMP5 in tissues of $S$. variegata, whereas individual addition of citric acid and tartaric acid significantly increased the expression of NRAMP5 in the roots, showing a consistent trend of variation in Cd content under organic acid treatment (Table 3). In contrast, the expression level of NRAMP5 in leaves was significantly improved by the citric acid and malic acid treatment, respectively. Previous studies found that Zn-MTPs such as AtMTP1, PtdMTP1, CsMTP1, AtMTP3, and CsMTP4 were mainly involved in the transportation and sequestration of vacuolar Zn and Cd (Blaudez et al., 2003; Kobae et al., 2004; Migocka et al., 2015). This study showed that the expression of MTP4 in the roots was considerably boosted by respective addition of citric acid and tartaric acid, which seemed to be associated with $\mathrm{Cd}$ absorption enhancement by the root of S. variegata (Table 3). HMAs play an important role in heavy metal hyperaccumulators and super-resistant plant species (Lee et al., 2007). Under Cd stress, HMA3 expression level was significantly suppressed and might be damaged. Individual addition of three organic acids increased the expression of HMA3 in roots and might thus improve plant tolerance. The expression of HMA1 in S. variegata significantly increased under Cd stress, and the tartaric acid and malic acid treatment further promoted the gene expression. Moreover, the addition of citric acid notably boosted the expression of HMA5 in roots and HMA1 and HMA3 in leaves. These results indicate that three exogenous organic acids improved the Cd tolerance of $S$. variegata through the stimulation of HMA1, HMA3, and HMA5 expression, especially in the roots of $S$. variegata. The PC peptide is a non-gene-coding product, and the PCS of PC synthetase family plays a key role in the synthesis of PC peptides (Picault et al., 2006). In this study, the expression level of PCS1 in the roots was drastically induced by $\mathrm{Cd}$, which was 30.45 times of that of CK. This suggests that PCS1 is very likely to be involved in the accumulation of Cd in roots of $S$. variegata. The respective addition of citric acid and tartaric acid further increased the expression of PCS1. As a contrast, malic acid addition reduced its expression, but it was still significantly higher than that of CK. In the leaves, the expression level of PCS1 was also significantly increased in $\mathrm{Cd}+$ citric acid and $\mathrm{Cd}+$ malic acid treatments. Decreased expression level of MT1A and MT2B in each treatment group and decreased PCS1 expression in the $\mathrm{Cd}+$ tartaric acid treatment group might be both related to the Cd accumulation in leaves of $S$. variegata.

\section{CONCLUSION}

This study showed that $\mathrm{Cd}$ exposure significantly inhibited plant biomass and provoked the activity of antioxidant enzymes, as well as MDA concentration in the tissues of $S$. variegata. Respective addition of the three organic acids greatly promoted plant resistance to oxidative stress and reduced the Cd-imposed lipid peroxidation, with the effect of malic acid showing greatest. However, citric acid markedly increased the total Cd accumulation of S. variegata compared with the other two organic acids. The addition of organic acids also significantly increased GSH content in the root, potentially further improving the antioxidant capacity and PC biosynthesis. Under the stress of $\mathrm{Cd}$, the candidate genes were mainly expressed in the roots of $S$. variegata, and the addition of three organic acids further promoted the expression of candidate genes in $S$. variegata. In conclusion, application of citric, tartaric, or malic acid alleviated Cd-imposed toxicity through the boost of enzymatic and non-enzymatic antioxidants and candidate gene expression, whereas their effects on $\mathrm{Cd}$ tolerance and accumulation of S. variegata differed.

\section{DATA AVAILABILITY STATEMENT}

The raw data supporting the conclusions of this article will be made available by the authors, without undue reservation.

\section{AUTHOR CONTRIBUTIONS}

SZ: conceptualization, methodology, visualization, validation, writing-original draft preparation, and writing-reviewing and editing. HC: conceptualization, methodology, investigation, data curation, visualization, writing-original draft preparation, and writing-reviewing and editing. DH: investigation, visualization, data curation, and writing-reviewing and editing. $\mathrm{XH}$ : investigation, data curation, and validation. YY: investigation, data curation, and validation. KW: investigation, data curation, and validation. HW: funding acquisition, conceptualization, resources, supervision, project administration, writingreviewing and editing. All authors: contributed to the article and approved the submitted version.

\section{FUNDING}

This work was financially supported by The National Key Research and Development Program of China (2017YFC0505305) and Southwest University Intelligent Ecological and Environmental Protection Discipline Funding. 


\section{REFERENCES}

Aebi, H. (1984). Catalase in vitro. Methods Enzymol. 105, 121-126. doi: 10.1016/ s0076-6879(84)05016-3

Ali, E., Maodzeka, A., Hussain, N., Shamsi, I. H., and Jiang, L. (2015). The alleviation of cadmium toxicity in oilseed rape (Brassica napus) by the application of salicylic acid. Plant Growth Regul. 75, 641-655. doi: 10.1007/ s10725-014-9966-0

Araujo, W. L., Nunes-Nesi, A., Nikoloski, Z., Sweetlove, L. J., and Fernie, A. R. (2012). Metabolic control and regulation of the tricarboxylic acid cycle in photosynthetic and heterotrophic plant tissues. Plant Cell Environ. 35, 1-21. doi: 10.1111/j.1365-3040.2011.02332.x

Beauchamp, C., and Fridovich, I. (1971). Superoxide dismutase - improved assays and an assay applicable to acrylamide gels. Anal. Biochem. 44, 276-287. doi: 10.1016/0003-2697(71)90370-8

Blaudez, D., Kohler, A., Martin, F., Sanders, D., and Chalot, M. (2003). Poplar metal tolerance protein 1 confers zinc tolerance and is an oligomeric vacuolar zinc transporter with an essential leucine zipper motif. Plant Cell 15, 2911-2928. doi: 10.1105/tpc.017541

Chen, H. C., Wu, K. J., Li, R., Wang, T., Zhou, C., Ma, W. C., et al. (2019). Effects of exogenous organic acids on the characteristics of $\mathrm{Cd}$ accumulation of Salix variegata Franch. Under Cd stress (in Chinese with English Abstract). Acta Ecol. Sin. 12, 1-8.

Chen, H. C., Zhang, S. L., Wu, K. J., Li, R., He, X. R., He, D. N., et al. (2020). The effects of exogenous organic acids on the growth, photosynthesis and cellular ultrastructure of Salix variegata Franch. Under Cd stress. Ecotoxicol. Environ. Saf. 187:109790. doi: 10.1016/j.ecoenv.2019.109790

Chmielowska-Bak, J., Gzyl, J., Rucinska-Sobkowiak, R., Arasimowicz-Jelonek, M., and Deckert, J. (2014). The new insights into cadmium sensing. Front. Plant Sci. 5:245. doi: 10.3389/fpls.2014.00245

Cuypers, A., Plusquin, M., Remans, T., Jozefczak, M., Keunen, E., Gielen, H., et al. (2010). Cadmium stress: an oxidative challenge. Biometals 23, 927-940.

Dias, M. C., Monteiro, C., Moutinho-Pereira, J., Correia, C., Goncalves, B., and Santos, C. (2013). Cadmium toxicity affects photosynthesis and plant growth at different levels. Acta Physiol. Plant. 35, 1281-1289. doi: 10.1007/s11738-0121167-8

do Nascimento, C. W. A., Amarasiriwardena, D., and Xing, B. S. (2006). Comparison of natural organic acids and synthetic chelates at enhancing phytoextraction of metals from a multi-metal contaminated soil. Environ. Pollut. 140, 114-123. doi: 10.1016/j.envpol.2005.06.017

Duan, G. L., Hu, Y., Liu, W. J., Kneer, R., Zhao, F. J., and Zhu, Y. G. (2011). Evidence for a role of phytochelatins in regulating arsenic accumulation in rice grain. Environ. Exp. Bot. 71, 416-421.

El-Beltagi, H. S., and Mohamed, H. I. (2013). Reactive oxygen species, lipid peroxidation and antioxidative defense mechanism. Not. Bot. Horti Agrobot. Cluj Napoca 41, 44-57. doi: 10.15835/nbha4118929

Gallego, S. M., Pena, L. B., Barcia, R. A., Azpilicueta, C. E., Lannone, M. F. Rosales, E. P., et al. (2012). Unravelling cadmium toxicity and tolerance in plants: insight into regulatory mechanisms. Environ. Exp. Bot. 83, 33-46. doi: 10.1016/j.envexpbot.2012.04.006

Gill, S. S., and Tuteja, N. (2010). Reactive oxygen species and antioxidant machinery in abiotic stress tolerance in crop plants. Plant Physiol. Biochem. 48, 909-930. doi: 10.1016/j.plaphy.2010.08.016

Gill, S. S., and Tuteja, N. (2011). Cadmium stress tolerance in crop plants probing the role of sulfur. Plant Signal. Behav. 6, 215-222. doi: 10.4161/psb.6.2.14880

Guo, H., Chen, H., Hong, C., Jiang, D., and Zheng, B. (2017). Exogenous malic acid alleviates cadmium toxicity in Miscanthus sacchariflorus through enhancing photosynthetic capacity and restraining ROS accumulation. Ecotoxicol. Environ. Saf. 141, 119-128. doi: 10.1016/j.ecoenv.2017.03.018

Guo, T. R., Zhang, G. P., Zhou, M. X., Wu, F. B., and Chen, J. X. (2004). Effects of aluminum and cadmium toxicity on growth and antioxidant enzyme activities of two barley genotypes with different Al resistance. Plant Soil 258, 241-248. doi: 10.1023/b:plso.0000016554.87519.d6

Guo, W. J., Meetam, M., and Goldsbrough, P. B. (2008). Examining the specific contributions of individual Arabidopsis metallothioneins to copper distribution and metal tolerance. Plant Physiol. 146, 1697-1706. doi: 10.1104/pp.108.115782

Han, Y., Wu, X., Gu, J., Zhao, J., Huang, S., Yuan, H., et al. (2016). Effects of organic acids on the photosynthetic and antioxidant properties and accumulations of heavy metals of Melilotus officinalis grown in Cu tailing. Environ. Sci. Pollut. Res. 23, 17901-17909. doi: 10.1007/s11356-016-6920-x

Hanikenne, M., Talke, I. N., Haydon, M. J., Lanz, C., Nolte, A., Motte, P., et al. (2008). Evolution of metal hyperaccumulation required cis-regulatory changes and triplication of HMA4. Nature 453, 391-395. doi: 10.1038/nature06877

Hartley-Whitaker, J., Ainsworth, G., Vooijs, R., Ten Bookum, W., Schat, H., and Meharg, A. A. (2001). Phytochelatins are involved in differential arsenate tolerance in Holcus lanatus. Plant Physiol. 126, 299-306. doi: 10.1104/pp.126. 1.299

Hasanuzzaman, M., Hossain, M. A., and Fujita, M. (2012). Exogenous selenium pretreatment protects rapeseed seedlings from cadmium-induced oxidative stress by upregulating antioxidant defense and methylglyoxal detoxification systems. Biol. Trace Elem. Res. 149, 248-261. doi: 10.1007/s12011-012-9419-4

Heyno, E., Klose, C., and Krieger-Liszkay, A. (2008). Origin of cadmium-induced reactive oxygen species production: mitochondrial electron transfer versus plasma membrane NADPH oxidase. New Phytol. 179, 687-699. doi: 10.1111/j. 1469-8137.2008.02512.x

Irfan, M., Hayat, S., Ahmad, A., and Alyemeni, M. N. (2013). Soil cadmium enrichment: allocation and plant physiological manifestations. Saudi J. Biol. Sci. 20, 1-10. doi: 10.1016/j.sjbs.2012.11.004

Jia, Z. M., Cheng, H., Wei, H., and Li, C. X. (2012). Photosynthetic responses of the riparian Salix variegata to cadmium stress in three gorges reservoir region. Sci. Silvae Sin. 48, 152-158.

Jia, Z. M., Wei, H., Sun, X. C., Li, C. X., Meng, X. F., and Xie, X. H. (2011). Accumulation and tolerance of Salix variegate and Pterocarya stenoptera seedlings to cadmium. Acta Ecol. Sin. 31, 107-114.

Jin, X. F., Yang, X. Q., Lslam, E., Liu, D., and Mahmood, Q. (2008). Effects of cadmium on ultrastructure and antioxidative defense system in hyperaccumulator and non-hyperaccumulator ecotypes of Sedum alfredii Hance. J. Hazard. Mater. 156, 387-397. doi: 10.1016/j.jhazmat.2007.12.064

Kaur, R., Yadav, P., Sharma, A., Thukral, A. K., Kumar, V., Kohli, S. K., et al. (2017). Castasterone and citric acid treatment restores photosynthetic attributes in Brassica juncea L. under Cd (II) toxicity. Ecotoxicol. Environ. Saf. 145, 466-475. doi: 10.1016/j.ecoenv.2017.07.067

Kobae, Y., Uemura, T., Sato, M. H., Ohnishi, M., Mimura, T., Nakagawa, T., et al. (2004). Zinc transporter of Arabidopsis thaliana AtMTP1 is localized to vacuolar membranes and implicated in zinc homeostasis. Plant Cell Physiol. 45, 1749-1758. doi: 10.1093/pcp/pci015

Lee, J., Shim, D., Song, W. Y., Hwang, I., and Lee, Y. (2004). Arabidopsis metallothioneins $2 \mathrm{a}$ and 3 enhance resistance to cadmium when expressed in Vicia faba guard cells. Plant Mol. Biol. 54, 805-815. doi: 10.1007/s11103-0040190-6

Lee, S., Kim, Y. Y., Lee, Y., and An, G. (2007). Rice P-1B-type heavy-metal ATPase, OsHMA9, is a metal efflux protein. Plant Physiol. 145, 831-842. doi: 10.1104/ pp.107.102236

Li, H. Y. (2014). The Effects of Exogenous Citric and Oxalic Acid on Cadmium Induced Physiological Response in Boehmeria nivea (L.) Gaud. Changsha: Hunan University, 32-50.

Li, T., Di, Z., Islam, E., Jiang, H., and Yang, X. (2011). Rhizosphere characteristics of zinc hyperaccumulator Sedum alfredii involved in zinc accumulation. J. Hazard. Mater. 185, 818-823. doi: 10.1016/j.jhazmat.2010.09.093

Liu, J., Zhang, H., Zhang, Y., and Chai, T. (2013). Silicon attenuates cadmium toxicity in Solanum nigrum L. by reducing cadmium uptake and oxidative stress. Plant Physiol. Biochem. 68, 1-7. doi: 10.1016/j.plaphy.2013.03.018

Liu, X., Song, Q., Tang, Y., Li, W., Xu, J., Wu, J., et al. (2013). Human health risk assessment of heavy metals in soil-vegetable system: a multi-medium analysis. Sci. Total Environ. 463, 530-540. doi: 10.1016/j.scitotenv.2013. 06.064

Livak, K. J., and Schmittgen, T. D. (2001). Analysis of relative gene expression data using real-time quantitative PCR and the 2- $\Delta \Delta \mathrm{Ct}$ method. Methods 25, 402-408. doi: 10.1006/meth.2001.1262

Luo, Z.-B., He, J., Polle, A., and Rennenberg, H. (2016). Heavy metal accumulation and signal transduction in herbaceous and woody plants: paving the way for enhancing phytoremediation efficiency. Biotechnol. Adv. 34, 1131-1148. doi: 10.1016/j.biotechadv.2016.07.003

Mahmud, J. A., Hasanuzzaman, M., Nahar, K., Bhuyan, M. H. M. B., and Fujita, M. (2018). Insights into citric acid-induced cadmium tolerance and phytoremediation in Brassica juncea L.: coordinated functions of metal 
chelation, antioxidant defense and glyoxalase systems. Ecotoxicol. Environ. Saf. 147, 990-1001. doi: 10.1016/j.ecoenv.2017.09.045

Memon, A. R., and Schroder, P. (2009). Implications of metal accumulation mechanisms to phytoremediation. Environ. Sci. Pollut. Res. 16, 162-175. doi: 10.1007/s11356-008-0079-z

Migeon, A., Blaudez, D., Wilkins, O., Montanini, B., Campbell, M. M., Richaud, P., et al. (2010). Genome-wide analysis of plant metal transporters, with an emphasis on poplar. Cell. Mol. Life Sci. 67, 3763-3784. doi: 10.1007/s00018010-0445-0

Migocka, M., Kosieradzka, A., Papierniak, A., Maciaszczyk-Dziubinska, E., Posyniak, E., Garbiec, A., et al. (2015). Two metal-tolerance proteins, MTP1 and MTP4, are involved in $\mathrm{Zn}$ homeostasis and Cd sequestration in cucumber cells. J. Exp. Bot. 66, 1001-1015. doi: 10.1093/jxb/eru459

Najeeb, U., Jilani, G., Ali, S., Sarwar, M., Xu, L., and Zhou, W. (2011). Insights into cadmium induced physiological and ultra-structural disorders in Juncus effusus L. and its remediation through exogenous citric acid. J. Hazard. Mater. 186, 565-574. doi: 10.1016/j.jhazmat.2010.11.037

Nakano, Y., and Asada, K. (1981). Hydrogen peroxide is scavenged by ascorbate-specific peroxidase in spinach chloroplasts. Plant Cell Physiol. 22, 867-880.

Nawaz, I., Iqbal, M., Bliek, M., and Schat, H. (2017). Salt and heavy metal tolerance and expression levels of candidate tolerance genes among four extremophile Cochlearia species with contrasting habitat preferences. Sci. Total Environ. 584, 731-741. doi: 10.1016/j.scitotenv.2017.01.111

Nickel, K. S., and Cunningham, B. A. (1969). Improved peroxidase assay method using leuco 2,3,6-trichloroindophenol and application to comparative measurements of peroxidatic catalysis. Anal. Biochem. 27, 292-299. doi: 10. 1016/0003-2697(69)90035-9

Pandey, N., and Singh, G. K. (2012). Studies on antioxidative enzymes induced by cadmium in pea plants (Pisum sativum). J. Environ. Biol. 33, 201-206.

Picault, N., Cazale, A. C., Beyly, A., Cuine, S., Carrier, P., Luu, D. T., et al. (2006). Chloroplast targeting of phytochelatin synthase in Arabidopsis: effects on heavy metal tolerance and accumulation. Biochimie 88, 1743-1750. doi: 10.1016/j. biochi.2006.04.016

Pottier, M., Oomen, R., Picco, C., Giraudat, J., Scholz-Starke, J., Richaud, P., et al. (2015). Identification of mutations allowing natural resistance associated macrophage proteins (NRAMP) to discriminate against cadmium. Plant J. 83, 625-637. doi: 10.1111/tpj.12914

Sanita di Toppi, L., and Gabbrielli, R. (1999). Response to cadmium in higher plants. Environ. Exp. Bot. 41, 105-130. doi: 10.1016/s0098-8472(98)00058-6

Schulze, J., Tesfaye, M., Litjens, R., Bucciarelli, B., Trepp, G., Miller, S., et al. (2002). Malate plays a central role in plant nutrition. Plant Soil 247, 133-139. doi: 10.1007/978-94-017-2789-1_10

Semane, B., Cuypers, A., Smeets, K., Van Belleghem, F., Horemans, N., Schat, H., et al. (2007). Cadmium responses in Arabidopsis thaliana: glutathione metabolism and antioxidative defence system. Physiol. Plant. 129, 519-528. doi: 10.1111/j.1399-3054.2006.00822.x
Smeets, K., Ruytinx, J., Semane, B., Van Belleghem, F., Remans, T., Van Sanden, S., et al. (2008). Cadmium-induced transcriptional and enzymatic alterations related to oxidative stress. Environ. Exp. Bot. 63, 1-8. doi: 10.1016/j.envexpbot. 2007.10.028

Sun, Q., Wang, X. R., Ding, S. M., and Yuan, X. F. (2005). Effects of exogenous organic chelators on phytochelatins production and its relationship with cadmium toxicity in wheat (Triticum aestivum L.) under cadmium stress. Chemosphere 60, 22-31. doi: 10.1016/j.chemosphere.2004.10.068

Sun, X. C., Wei, H., Xie, X. H., Jia, Z. M., and Meng, X. F. (2012). Bioaccumulation and photosynthesis response of Salix variegate to cadmium under hydroponic culture. Res. Environ. Sci. 25, 220-225.

Touiserkani, T., and Haddad, R. (2012). Cadmium-induced stress and antioxidative responses in different Brassica napus cultivars. J. Agric. Sci. Technol. 14, 929-937.

Wang, P., Deng, X. J., Huang, Y. A., Fang, X. L., Zhang, J., Wang, H. B., et al. (2016). Dynamic changes of cadmium and non-protein thiol in different organs of different soybean genotypes under cadmium stress (in Chinese with English abstract). J. S. China Agric. Univ. 37, 42-50.

Wang, Y. D., Fang, J., Leonard, S. S., and Rao, K. M. K. (2004). Cadmium inhibits the electron transfer chain and induces reactive oxygen species. Free Radic. Biol. Med. 36, 1434-1443. doi: 10.1016/j.freeradbiomed.2004.03.010

Wong, M. H. (2003). Ecological restoration of mine degraded soils, with emphasis on metal contaminated soils. Chemosphere 50, 775-780. doi: 10.1016/s00456535(02)00232-1

Wuana, R. A., Okieimen, F. E., and Imborvungu, J. A. (2010). Removal of heavy metals from a contaminated soil using organic chelating acids. Int. J. Environ. Sci. Technol. 7, 485-496. doi: 10.1007/bf03326158

Yamaguchi, N., Mori, S., Baba, K., Kaburagi-Yada, S., Arao, T., Kitajima, N., et al. (2011). Cadmium distribution in the root tissues of solanaceous plants with contrasting root-to-shoot Cd translocation efficiencies. Environ. Exp. Bot. 71, 198-206. doi: 10.1016/j.envexpbot.2010.12.002

Yang, Y., Wang, M., Liu, X. Y., Zhen, Q., Chu, L., and Liu, D. Y. (2007). Effects of organic acids on the growth of rape under Cd stress. J. Anhui Norm. Univ. 30, $158-162$.

Yuan, L., Yang, S., Liu, B., Zhang, M., and Wu, K. (2012). Molecular characterization of a rice metal tolerance protein, OsMTP1. Plant Cell Rep. 31, 67-79. doi: 10.1007/s00299-011-1140-9

Conflict of Interest: The authors declare that the research was conducted in the absence of any commercial or financial relationships that could be construed as a potential conflict of interest.

Copyright (c) 2020 Zhang, Chen, He, He, Yan, Wu and Wei. This is an open-access article distributed under the terms of the Creative Commons Attribution License (CC BY). The use, distribution or reproduction in other forums is permitted, provided the original author(s) and the copyright owner(s) are credited and that the original publication in this journal is cited, in accordance with accepted academic practice. No use, distribution or reproduction is permitted which does not comply with these terms. 